\title{
Flammability Characteristics of Green Roofs
}

\author{
Nataliia Gerzhova ${ }^{1, *}{ }^{\oplus}$, Pierre Blanchet ${ }^{1} \oplus$, Christian Dagenais ${ }^{1,2} \oplus$, Sylvain Ménard ${ }^{3}$ \\ and Jean Côté 4 \\ 1 Department of Wood and Forest Sciences, Université Laval, Québec, QC G1V 0A6, Canada; \\ Pierre.Blanchet@sbf.ulaval.ca (P.B.); Christian.Dagenais@fpinnovations.ca (C.D.) \\ 2 FPInnovations, Québec, QC G1V 4C7, Canada \\ 3 Department of Applied Sciences, Université du Québec à Chicoutimi (UCAQ), \\ Chicoutimi, QC G7H 2B1, Canada; Sylvain_Menard@uqac.ca \\ 4 Department of Civil and Water Engineering, Université Laval, Québec, QC G1V 0A6, Canada; \\ Jean.Cote@gci.ulaval.ca \\ * Correspondence: nataliia.gerzhova.1@ulaval.ca
}

Received: 29 May 2020; Accepted: 4 July 2020; Published: 9 July 2020

\begin{abstract}
Assessing the fire risk of vegetated roofs includes the determination of their possible contribution to fire. Green roof components such as plants and growing media are organic materials and present a fuel that can catch and support the spread of fire. The flammability characteristics of these components were analyzed and compared to a typical roof covering. Growing media with $15 \%$ of organic matter were tested using cone calorimeter apparatus. The fuel load and heat release rate of the growing media were measured in both moist (30\%) and dry conditions. It was observed that growing media in a moist condition do not present a fire risk, reaching a maximum heat release rate of $33 \mathrm{~kW} / \mathrm{m}^{2}$. For dry substrates, a peak heat release rate of $95 \mathrm{~kW} / \mathrm{m}^{2}$ was recorded in the first minute, which then rapidly decreased to $29 \mathrm{~kW} / \mathrm{m}^{2}$ in the second minute. Compared to a typical bitumen roof membrane, the green roof showed a better fire performance. The literature data report more severe results for plant behavior, reaching peak heat release rates (HRRs) of $397 \mathrm{~kW} / \mathrm{m}^{2}$ for dried and $176 \mathrm{~kW} / \mathrm{m}^{2}$ for a green material. However, a rapid decrease in HRR to much lower values occurs in less than $2 \mathrm{~min}$. The results also show that extensive and intensive types of green roofs present $22 \%$ and $95 \%$ of the additional fire load density when installed on a modified bitumen membrane, 19.7 and $85.8 \mathrm{MJ} / \mathrm{m}^{2}$, respectively.
\end{abstract}

Keywords: green roof; fire; flammability; heat release rate

\section{Introduction}

Currently, plants are being successfully used as an environmental improvement tool. One of the examples of this contemporary technology is the installation of vegetation on roofs and walls of buildings, which helps to improve the ecology and social life in urban areas. This has been demonstrated by numerous scientific studies on various aspects, such as reduction of water runoff, increased energy efficiency of buildings, bringing aesthetic value and increased biodiversity by providing a natural habitat [1-5]. Studies make a great contribution to the development of these systems and to the promotion of the installation. The safety of green roofs, however, is poorly studied, namely in terms of the fire hazard. It is still debated whether the presence of such roofs possess a risk to the building and to what extent. The primary concern is the combustibility of green roof components, such as plants and soil organic matter (OM), which are claimed to present an additional fuel load that can contribute to fire [6,7]. In fire design, little attention is paid to roofs, because as non-living spaces they pose a very low risk of fire exposure for the occupants. This conforms to the primary objective of the building code for fire safety (NBC) [8], to limit the risk for the occupants. Moreover, unlike the interior of the 
building, these spaces are not confined, and the amount of stored combustible materials on top of the roof is restricted. However, green roofs fully covered by vegetation, especially in cases of intensive greening, appear to store some amount of fuel continuously distributed on their surface, presented by the organic material in soil and plants. The possibility of such fuel to be ignited and to develop a fire was confirmed by the recent small green roof fires that happened in Portland (OR, USA) and London (UK) in the summer of 2018 [9,10]. From the available information, dried overgrown grass caught on fire from a spark in the first case. In the second, low extensive greening was ignited, possibly by a cigarette. Sustained flaming appeared, which spread over a roof deck and a wall nearby. Both fires were extinguished by firefighters.

The flammability characteristics of organic materials, such as peat [11], leaf litter [12], forest litter in the form of pine needles [13], ornamental vegetation [14] and various plant species (leaves and twigs) [15] have been reported. However, studies on organic soil flammability or green roof substrates are difficult to find. A British report on the fire safety of green roofs investigated the behavior of dry green roof substrates in terms of ignitability and heat release rate (HRR) at a small scale using a cone calorimeter [16]. The document concluded a good performance for a standard mix showing either no ignition, or in the case of ignition, no sustained flaming. The report contains general conclusions and no details were given as for the tested samples (composition and amount of OM in the soil blend), test procedure and the description of results. Moreover, only dry material was tested, assuming the most dangerous case. Comparisons with a substrate containing some amount of moisture, as in real conditions, can provide a better idea of the fire hazard of the substrate. Another interesting comparison is given in the literature as for the advantages of a green roof over a conventional one in fire performance. It was stated that a dry extensive green roof with dry grass releases much less heat $\left(3 \mathrm{kWh} / \mathrm{m}^{2}\right)$ than a typical bituminous roof membrane $\left(50 \mathrm{kWh} / \mathrm{m}^{2}\right)$ [17]. A description of the experiment was not given and therefore it is not clear what the test conditions (test method) and the parameters of the green roof assembly were (soil organic product, the amount of vegetation material, moisture content).

Additional information on combustible characteristics of green roof substrates, as well as a summary of the fire load, composed of substrates and vegetation, can contribute to the knowledge on the fire hazards of these systems. The objectives of this study are to determine the potential amount of fuel that is presented by a green roof, the heat release rate produced by green roof materials in case of fire, and to compare this to a conventional type of roof.

\section{Background}

\subsection{Fuel Load}

The protection of a building from fire by a safety design involves the development of fire scenarios that may occur in the building. Necessary information includes the characterization of the building in terms of the quantity of combustible materials (fuel) that presents a certain fire load [18]. The fire load in buildings is usually expressed as the amount of energy per area (fire load density, $\mathrm{MJ} / \mathrm{m}^{2}$ ), which can be calculated by knowing the mass of fuel per area (fuel load) $\left(\mathrm{kg} / \mathrm{m}^{2}\right)$ and the energy content of this fuel $(\mathrm{MJ} / \mathrm{kg})$. The amount of fire load is necessary in the prediction of temperatures during a fire inside a compartment. It is also one of the parameters that influences HRR, which is the main characteristic of fire severity in buildings [19]. In vegetation fires, or wildfires, the prediction of fire behavior differs from that of the building, concerning not only the intensity of fire but also its rate of spread, which depends on multiple factors. The fuel load presented by various plant materials is one such factor.

When estimating fuel load, it is important to consider its availability. For example, the moisture of a plant material reduces the availability of fuel. Its increased content in live plants makes them act as a heat sink, rather than a source of fuel [20]. Dead plant material with a low moisture content burns more easily. The difficulty in estimating the amount of available fuel presented by vegetation in 
wildlands is that it always changes due to the transition of plant parts from live to dead, provoked by a seasonal fluctuation in moisture.

Another indicator of the fuel availability is the direct disposition to flames (fuel density, fuelbed porosity) and fuel thickness (fuel surface-to-volume ratio) [19]. For example, grass, leaves and small shrubs are fine fuels, which are considered highly susceptible to fire. Their high surface-area-to-volume ratio and the small size of their particles allow them to dry out during hot periods, increasing the risk of being ignited and contributing to fire [21]. Such material burns quickly and can be expected to be consumed completely in fire. Moreover, since it does not require much heat input to lose moisture, in the case of an existing fire, live herbaceous plant material cannot always effectively resist the flame spread. Plants with particles of lower surface-area-to-volume ratio (particle diameter over 0.25 in) require more time to be completely burned, releasing energy more slowly. The moisture presented in such fuels requires a lot of energy input to be driven out. Another example of fuel availability is organic material in soil, which, for green roof growing media, is usually in the form of peat and compost, which are mixed with mineral components and packed. In soil, the access to air is limited, and thus the combustion occurs mostly at the surface layer, whereas incomplete combustion occurs underneath, which means that not all fuel will be consumed. Both large plants and organic soil are considered thick fuels [22].

\subsection{Vegetation}

A large amount of data on vegetative fuel load exists in the literature. This can be found in the default data for different types of wildlands as input parameters for wildfire modeling. Several sets of fuel models have been elaborated in the USA [23-25] and Canada [26] that describe fuelbed parameters, such as the amount of dead (fine, medium, large) and live fuel load per area, type of vegetation, fuel depth (height) and energy content. Fuel data are also available for Australian and some European and African wildlands to be used in the models [27-31].

Fuel load can also be presented as the amount of biomass (organic part of a plant, typically dry weight is taken). In wildfires, plant biomass is not always regarded as a total fuel, because of a reduction in fuel availability. However, each green roof is unique, which means their fuelbed parameters are different in each case. Assumptions of the most hazardous case can show the potential contribution of different types of green roofs to fire, and therefore the data on the biomass can be considered as a total fuel load.

There are several categories of green roofs (Figure 1) that differ mostly by the type of vegetation and the thickness of the growing medium necessary to support the plants. Extensive green roofs with a shallow layer of substrate are planted with low-growing herbaceous plants, grasses, Sedums and mosses. A $10-\mathrm{cm}$ thickness of growing medium with low organic matter (OM) content $(2-5 \%$ by mass) is usually enough to support such plants. Semi-intensive roofs have a greater variety of plants, including small shrubs. Intensive green roofs are usually roof gardens with diverse vegetation, from simple grasses to shrubs and small trees. A growing medium rich in OM (up to 20\%) and a larger thickness is required. Each of these categories of roofs thus stores a certain range of fuel load. It must be noted that succulents, typically used for simple extensive green roofs, do not carry fire easily, unlike other plants, because of their ability to store great amount of moisture. Their specific structure does not allow for the loss of water at a high rate. This helps them to survive even in severe drought periods. Their contribution to fire risk therefore can be neglected. Trees (installed on roof gardens) can also be excluded from fuel estimation due to the large diameter of their particles. Thus, only some fine fuels, herbaceous plants and shrubs with branches of small diameters should be considered.

To have an idea of the amount of fuel load presented by each of the categories of green roofs, existing data on the biomass of species grown on roofs can be used. Moreover, each category can be associated with a certain wildland (or fuel model). Existing data on the fuel parameters (biomass) of vegetation can be sorted into three categories: extensive greening (low grass, that is, up to $0.5 \mathrm{~m}$ height); semi-intensive (includes tall ornamental grasses of $0.5-1.5 \mathrm{~m}$ height, and small shrubs of less 
than $1 \mathrm{~m}$ ); intensive (includes tall shrubs of more than $1 \mathrm{~m}$ height). For shrublands, data are sometimes given at a certain percentage of cover (between 10\% and $99 \%$ in the literature), which is acceptable, since intensive green roofs contain only inclusions of tall vegetation, not being covered completely. Thus, the percentage of vegetation cover may not be considered. Wildland types or fuel models can be ascribed to each category.

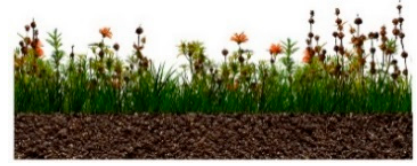

(a)

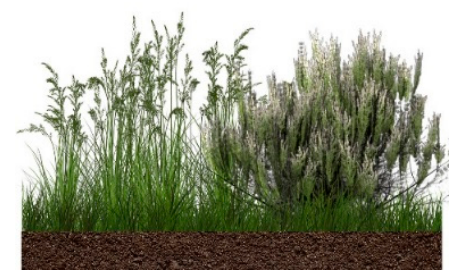

(b)

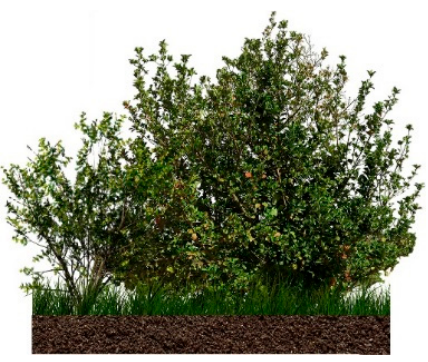

(c)

Figure 1. Green roof categories: (a) extensive (with low grass); (b) semi-intensive (with tall grass and low shrubs); (c) intensive (with tall shrubs).

Tables 1-3 present the data on fuel load for vegetation of each roof category. Fuel types were collected from sources of the models and measured values of specific wildlands vegetation from other studies on fire behavior in wildlands and on the aboveground biomass accumulation. Models include fine dead fuel, which is presented by particle diameters of less than one inch $(2.5 \mathrm{~cm})$, also called 1- and 10-h fuels. They also include live herbaceous material. Other fuels, such as dead fuels with more than one-inch diameters, and live woody fuels, are not considered.

Table 1. Fuels chosen for extensive green roofs.

\begin{tabular}{lcc}
\hline \multicolumn{1}{c}{ Fuel } & Total Fuel Load $\mathbf{~ k g} / \mathbf{m}^{\mathbf{2}}$ & Reference \\
\hline 1 (short grass) & 0.18 & {$[32]$} \\
A (Western annual grass) & 0.13 & {$[24]$} \\
L (Western perennial grass) & 0.19 & \\
GR-1 & 0.10 & {$[25]$} \\
GR-2 (sparse or grazed grass) & 0.27 & {$[26]$} \\
O-1a, O-1b (grass) & 0.30 & {$[31]$} \\
Understory of native grasses & 0.39 & {$[30]$} \\
Grasslands & 0.40 & \\
\hline
\end{tabular}

Table 2. Fuels chosen for semi-intensive green roofs.

\begin{tabular}{lcc}
\hline \multicolumn{1}{c}{ Fuel } & $\begin{array}{c}\text { Total Fuel Load } \\
\mathbf{~ k g} / \mathbf{m}^{\mathbf{2}}\end{array}$ & Reference \\
\hline 3 (tall grass) & 0.74 & {$[32]$} \\
5 (short shrub cover) & 0.86 & \\
N (grass prairie) & 0.75 & {$[24]$} \\
T (sparse shrubs and grass) & 0.50 & \\
GR 3-4 (grass) & 0.49 to 0.53 & \\
GS 1-4 (grass shrub) & 0.17 to 1.41 & {$[25]$} \\
SH 1-3, 6 (brush) & 0.16 to 1.11 & \\
Ornamental grass (sideoats grama, green needlegrass, Indian grass) & 0.37 to 0.75 & {$[33]$} \\
Tall grass species & 0.80 (average) & {$[34]$} \\
Moorland (low young shrubs) & 0.24 to 1.53 & {$[29]$} \\
Button grass moorland & 1.10 to 1.60 & {$[27]$} \\
\hline
\end{tabular}


Table 3. Fuels chosen for intensive green roofs.

\begin{tabular}{lcc}
\hline \multicolumn{1}{c}{ Fuel } & Total Fuel Load $\mathbf{~ k g} / \mathbf{m}^{\mathbf{2}}$ & Reference \\
\hline 7 (Brush) & 0.83 & {$[32]$} \\
D (Southern rough) & 0.81 & {$[24]$} \\
SH-5 (Chaparral) & 1.41 & {$[25]$} \\
SH-7 (Brush) & 2.17 & {$[35]$} \\
Shrub-steppe & 0.95 & {$[28]$} \\
Shrubland & 0.78 to 1.51 & {$[36]$} \\
Moorland (High density, 1 m height) & 2.00 & {$[37]$} \\
Mediterranean shrubs & 1.1 to 2.4 & {$[27]$} \\
Heathland & 1.4 to 2.47 & {$[38]$} \\
Shrubs (heath, gorse, broom) & 1.90 to 2.63 & \\
\hline
\end{tabular}

In the studies on plant biomass, descriptions of a type of vegetation and its height are usually given. No division by the diameter size or live and dead material of plants could be found. However, from the description in the studies used, it is clear that the vegetation does not present thick fuel. For the most hazardous case, it can be assumed that the live woody material of these plants can also present the fuel load. Thus, the total biomass was included. Data on the biomass of separate species of tall ornamental grasses such as switchgrass (Panicum virgatum), big bluestem (Andropogon gerardii), little bluestem (Schizachyrium scoparium), mammoth wildrye (Leymus racemosus) and Western wheatgrass (Pascopyrum smithii), which are used on green roofs [39-41], can be found in other studies. These values, however, may not be realistic for green roofs, as the studied areas present tall and dense stands, and therefore do not represent the accumulation of fuel load on a roof. For example, for mammoth wildrye, switchgrass and big bluestem, the range of maximum values found is $1.58-1.7 \mathrm{~kg} / \mathrm{m}^{2}$, with a mean value of $1.64 \mathrm{~kg} / \mathrm{m}^{2}$ [33,42]. For little bluestem and Western wheatgrass it is $1.2-1.25 \mathrm{~kg} / \mathrm{m}^{2}$ [43].

\subsection{Growing Medium}

The growing medium for a green roof usually contains some amount of OM in different forms, such as peat, compost and sawdust. The proportion of organics in the soil mix varies between 2-3 and $20-25 \%$ by mass. The thickness of a substrate layer varies depending on the type of vegetation it supports. The minimum thickness is usually not less than $5 \mathrm{~cm}$. Typically, for extensive greening, $10 \mathrm{~cm}$ is taken; for intensive green roofs, a greater depth is needed. Because soil is a thick fuel, only its available part (organic matter in the combustion depth) can be considered in fuel loading. During wildfires, heat does not usually penetrate deep into the soil, because soil in the dry state is a poor heat conductor, and the in moist state, a lot of energy needs to be applied to evaporate the water first. Measured temperatures in natural fires rarely exceed $100{ }^{\circ} \mathrm{C}$ at a depth of $5 \mathrm{~cm}$. For example, temperatures were recorded in the range of 49 and $66^{\circ} \mathrm{C}$ at a depth of $5 \mathrm{~cm}$; at a depth of $2.5 \mathrm{~cm}$, temperatures varied between 57 and $174^{\circ} \mathrm{C}$ for dry soil in chaparral fires [44]. Higher temperatures are given by Beadle [45] and Busse et al. [46] for a $2.5 \mathrm{~cm}$ depth, 250 and $370{ }^{\circ} \mathrm{C}$, respectively. Because of the absence of record temperatures reached in green roof soils in fires, which also differ from natural soils, it can be assumed that a layer of $2.5 \mathrm{~cm}$ in depth can contribute to fire. Growing media fuel parameters can be determined experimentally.

In addition to the vegetation and substrate, the assembly of a green roof contains other combustible materials, such as drainage panels (recycled polyethylene), a filter cloth (geotextile) and a root barrier (high-density polyethylene). As they are covered by a layer of soil, usually not less than $5 \mathrm{~cm}$ thickness, it can be assumed that they cannot present a fire load, as their availability for combustion is limited.

\section{Materials and Methods}

\subsection{Flammability Characteristics}

In fire engineering, the combustion performance of materials is usually investigated using the cone calorimeter apparatus. It is a standard method of measuring the flammability properties of a 
material, such as HRR, time to ignition, mass loss rate, smoke and toxic gas production [47]. In the experiment, a small sample is exposed to a uniform radiant heat flux of a constant intensity (up to $100 \mathrm{~kW} / \mathrm{m}^{2}$ ) and, with a spark igniter, the surface of the sample is ignited.

To evaluate the hazard that a green roof substrate represents in terms of its fire response, its performance was experimentally investigated with this method. For a better understanding of the scale of the risk, the obtained results were compared to existing data on waterproofing membranes tested in the same conditions. The following properties of the green roof substrate were measured: total heat released, HRR and time to ignition.

Few studies have been conducted on the fire properties of typical roof-covering materials using a cone calorimeter. In conventional types of roof coverings, the top layer is a waterproof membrane, which is made of combustible materials. One of the most common waterproof membranes used under green roof systems is polymer-modified bitumen (PMB). Data on its flammability parameters, such as HRR, average and peak HRR (pHRR), time to ignition, as well as the effect of ageing and fire retardant additives on these parameters, are available in the literature $[48,49]$.

\subsection{Testing Procedure}

The growing media were tested using a cone calorimeter fabricated by the Fire Testing Technology company (UK). Experiments were performed to determine HRR, as one of the most significant indicators of the fire hazard of materials [50]. Ignitability, pHRR and average HRR parameters were also measured. Tests were carried out in accordance with ISO 5660-1 "Reaction-to-fire tests-Heat release, smoke production and mass loss rate" [51]. In the absence of guidance on choosing a heating load specifically for green roof substrates and a lack of information on real fires on such roofs, a mean radiating heat flux of $50 \mathrm{~kW} / \mathrm{m}^{2}$ was used in the experiments. Such an irradiance level can represent small-scale fires [52]. The duration of each test was 15 min or until no heat was released. For each substrate in wet and dry conditions, the test was repeated three to five times or more to obtain reliable data.

\subsection{Materials and Sample Preparation}

Two commercial growing media mixes that are used in Quebec for extensive green roofs were taken for the study (Substrate 1 and 2), shown in Figure 2a,b. The OM content of both materials was $20 \pm 3 \%$ by mass. The two substrates were different in the composition of their components. The inorganic part of the first mix was in the form of a lightweight aggregate (slag) and a small amount of sand; the second mix contained expanded shale and perlite. Organic products were the composting material and peat moss in different proportions for each substrate.

To evaluate the effect of presence of moisture in the substrate on its fire behavior, samples were tested in both dry and moist conditions. In natural conditions, the moisture content (MC) of soil can vary greatly depending on multiple parameters such as season, time of day, weather and irrigation. It also depends on soil composition, soil particle characteristics and the ability of its components to absorb certain amounts of water. Because of this, analyzing the effect of a whole range of MC will be representative only of the substrates tested. This study focuses on general comparison of the fire hazard in the most severe case (dry state) and real conditions (with a certain level of MC). Therefore, only one moisture condition ( $30 \%$ of MC), which was chosen arbitrarily, was considered for the analysis. To eliminate water from the substrates, samples were placed in an oven at $105^{\circ} \mathrm{C}$ for $24 \mathrm{~h}$. Moist samples were prepared by adding water to an oven-dried soil, and then sealing them in plastic bags for 1 week. The dry weight of a substrate was the same for dry and moist samples, and was equal to $80 \pm 5 \mathrm{~g}$.

The standard specimen holder of the cone calorimeter was used for the test, consisting of a metal sample pan of $100 \times 100 \mathrm{~mm}$ and a metal edge frame of $50 \mathrm{~mm}$ in height. When installing it into in the holder, the substrate was manually compacted, and the surface was flattened. Figure $2 \mathrm{c}$ shows a sample of a dry substrate in a specimen holder. 


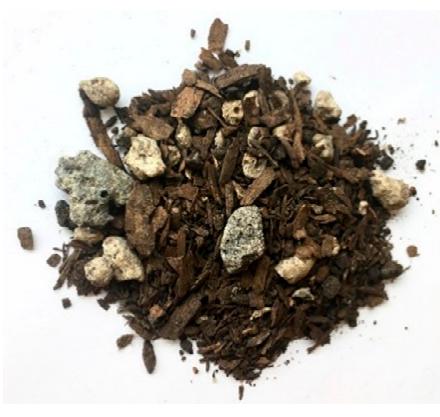

(a)

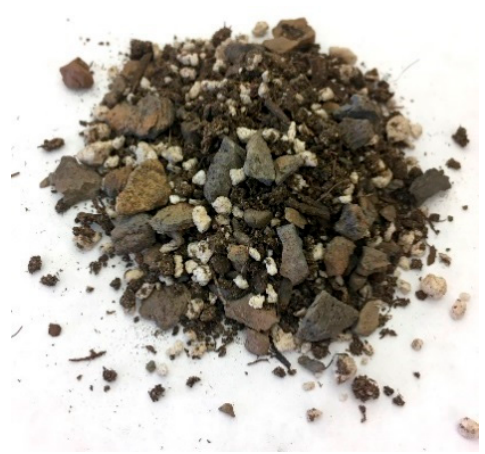

(b)

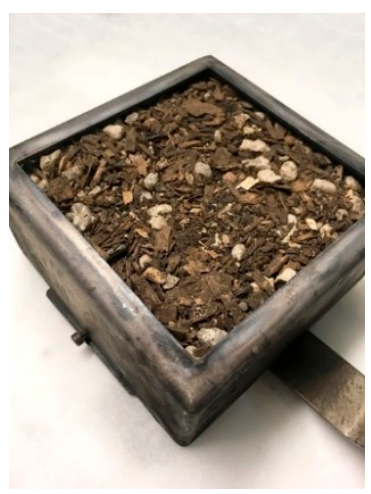

(c)

Figure 2. Samples: (a) Substrate 1; (b) Substrate 2; (c) sample in a holder.

\section{Results and Discussion}

\subsection{Fire Load Density of Green Roofs}

The total fire load density of vegetated roofs includes vegetation fuel and the top of the growing media. Fire loads of the two types of growing media in the dry state were determined in the cone calorimeter. The obtained values of total heat released were calculated for a $2.5 \mathrm{~cm}$ thickness of each sample (with $15 \%$ of OM) and were equal to 36.9 and $14.1 \mathrm{MJ} / \mathrm{m}^{2}$ for Substrate 1 and Substrate 2, respectively. It is assumed that fire loads of substrates with smaller amounts of OM can be obtained from these values by calculation per percent of OM.

The fire load densities of vegetation were calculated by multiplying fuel loads by their energy (heat) content. Studies on the heat content of vegetation showed that it depends largely on plant species. For example, for tall grasses, the reported range of values is 16.8 to $19.1 \mathrm{MJ} / \mathrm{kg}$ [53,54]. The averaged value of 17.3 MJ/kg was found by Kidnie [34] for different tall grasses. From the experimental research on several Mediterranean shrub species (tested twigs and leaves), the heating value was between 19.9 and $22.9 \mathrm{MJ} / \mathrm{kg}$ [55]. However, in fire prediction systems, usually one value is used for all fuel models, such as $18.6 \mathrm{MJ} / \mathrm{kg}$ in the U.S. [25] and $18 \mathrm{MJ} / \mathrm{kg}$ in Canadian Forest Fire Behavior Prediction (FBP) System [56].

Table 4 presents fire load densities for three types of vegetation cover in each of the green roof categories, and for the growing media. The energy content for vegetation was assumed to be $18.6 \mathrm{MJ} / \mathrm{kg}$. The obtained values for the vegetation are given in the ranges, while, for the growing media, the higher result of Substrate 1 was taken, which presents a higher risk. Extensive and semi-intensive green roofs included substrates with 5\% OM, intensive roofs included substrates with 15\% OM.

Table 4. Fire load density of green roof and its components.

\begin{tabular}{cc}
\hline Component & Fire Load Density $\mathbf{M J} / \mathbf{m}^{\mathbf{2}}$ \\
\hline Vegetation & \\
Extensive & 1.9 to 7.4 \\
Semi Intensive & 3.2 to 29.8 \\
Intensive & 15.1 to 48.9 \\
Growing medium (Substrate 1, 2.5-cm combustion zone) & \\
$5 \%$ OM & 12.3 \\
15\% OM & 36.9 \\
Green roof category & \\
Extensive & 14.2 to 19.7 \\
Semi-Intensive & 15.5 to 42.1 \\
Intensive & 52.0 to 85.8 \\
\hline
\end{tabular}


When comparing these data with a conventional roof covering made of a modified bitumen membrane, which is composed of $90.4 \mathrm{MJ} / \mathrm{m}^{2}$ [48], it can be seen that the green roof with extensive greening presents about $22 \%$ of the additional fire load, semi-intensive presents up to $47 \%$ and intensive greening up to $95 \%$.

\subsection{Combustibility}

\subsubsection{Growing Media}

Figure 3 presents HRR curves obtained in the experiment for two commercial substrate mixes (Substrate 1 and 2) with $15 \%$ of OM in dry and moist conditions. It is seen that moist substrates release much less heat than in the dry state, reaching pHRRs of 33 and $24 \mathrm{~kW} / \mathrm{m}^{2}$ and only after $8 \mathrm{~min}$, which presents a very low risk. In dry substrates, pHRRs are reached in the first few seconds and are equal to 95 and $64 \mathrm{~kW} / \mathrm{m}^{2}$, which is three times higher than those for the moist substrates. However, after only about a minute, these values decreased to 29 and $22 \mathrm{~kW} / \mathrm{m}^{2}$ and, until the end of the test, did not exceed 40 and $30 \mathrm{~kW} / \mathrm{m}^{2}$ for each substrate, respectively. In Figure 3, the curve for a typical roof covering, from a study by Bourbigot et al. [49], is shown for comparison. The material is a roof membrane made of PMB with fire retardants. Peak HRR is not much greater than that of dry substrates at the first peak. However, it does not decrease much, continuing to release heat for a much longer period, increasing to $162 \mathrm{~kW} / \mathrm{m}^{2}$ at the second peak after $10 \mathrm{~min}$.

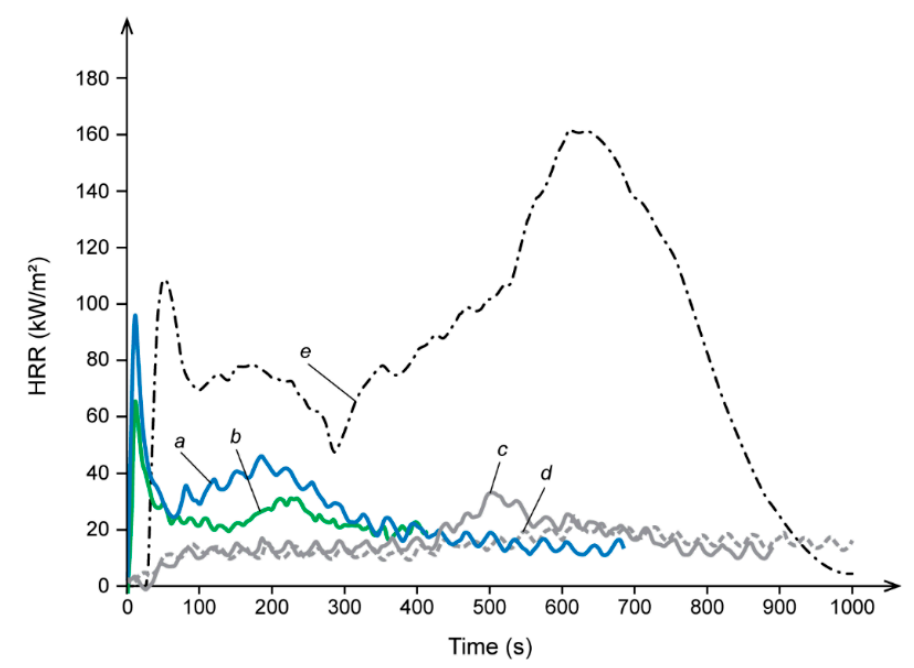

Figure 3. Comparison of heat release rate (HRR) of green roof substrates at dry and moist state with typical roof covering: (a) Substrate $1(0 \%$ moisture content $(\mathrm{MC}))$; (b) Substrate $2(0 \% \mathrm{MC})$; (c) Substrate 1 (30\% MC); (d) Substrate 2 (30\% MC); (e) polymer-modified bitumen (PMB) membrane with fire retardants (redrawn from Bourbigot et al. [49]).

A comparison can also be made to a membrane of the same material but without fire retardants. The results from another study show that the pHRR of such a material reaches $498 \mathrm{~kW} / \mathrm{m}^{2}$, staying at more than $100 \mathrm{~kW} / \mathrm{m}^{2}$ at first $6 \mathrm{~min}$ [48]. The mean HRRs of dry Substrates 1 and 2 in the first $5 \mathrm{~min}$ are equal to 37 and $27 \mathrm{~kW} / \mathrm{m}^{2}$, respectively. Compared to the membrane from the same study with the result of $260 \mathrm{~kW} / \mathrm{m}^{2}$ in the same period, it is more than seven times lower.

There is a small difference in the results of two types of dry substrates, which is explained by the difference in the organic products and their proportions (compost and peat), which burn differently. Compost is presented in Substrate 1 in much larger proportions than peat. This can also explain the flaming in moist substrates, which for Substrate 2 was not observed, as shown in Table 5. Moreover, the maximum duration of flames observed in soils was about $5 \mathrm{~min}$, while, in the membrane, the flaming ceased after $13 \mathrm{~min}$. 
Table 5. Times to ignition (seconds) and flameout for dry and moist substrates.

\begin{tabular}{|c|c|c|c|c|}
\hline \multirow{3}{*}{ Sample } & \multicolumn{2}{|c|}{$0 \% \mathrm{MC}$} & \multicolumn{2}{|c|}{$30 \% \mathrm{MC}$} \\
\hline & Ignition & Flameout & Ignition & Flameout \\
\hline & s & $\mathrm{s}$ & $\mathrm{s}$ & s \\
\hline Substrate 1 & 5 & 560 & 462 & 686 \\
\hline Substrate 2 & 7 & 294 & \multicolumn{2}{|c|}{-1} \\
\hline
\end{tabular}

\subsubsection{Vegetation}

Data on vegetation flammability characteristics tested in a cone calorimeter can be found in several studies $[14,57,58]$. The results show that HRR differs a lot depending on the species and moisture content of plants. Measured pHRRs of different northeastern USA plants were in the range of 30 and $397 \mathrm{~kW} / \mathrm{m}^{2}$ [57]. In the research of Weise et al. [14], the pHRR of dried plant material was between 49 and $331 \mathrm{~kW} / \mathrm{m}^{2}$, and for green material (with high MC) it was between 1 and $176 \mathrm{~kW} / \mathrm{m}^{2}$. However, in both studies, HRRs of more than $50 \mathrm{~kW} / \mathrm{m}^{2}$ were observed for no more than two consecutive minutes. The example of the HRR curve produced by vegetation is taken from the experimental study of Madrigal et al. [58] on European gorse (shrub), and is shown in Figure 4. Here, the curve is also compared to the results of the bitumen membranes. It can be assumed that vegetation from this research presents intensive greening (the fuel load specified in the study is between 1.6 and $3.1 \mathrm{~kg} / \mathrm{m}^{2}$ ). Figure 4 shows HRRs separately for dead (leaves and twigs of small diameters with $25 \% \mathrm{MC}$ ) and live (green leaves with $75 \% \mathrm{MC}$ ) plant material. It is seen that curves of both components rapidly increase, reaching maximum values of 332 and $190 \mathrm{~kW} / \mathrm{m}^{2}$ for dead and live parts, respectively, but after about $2 \mathrm{~min}$ they rapidly decrease to about $25 \mathrm{~kW} / \mathrm{m}^{2}$ and continue to decrease after this.

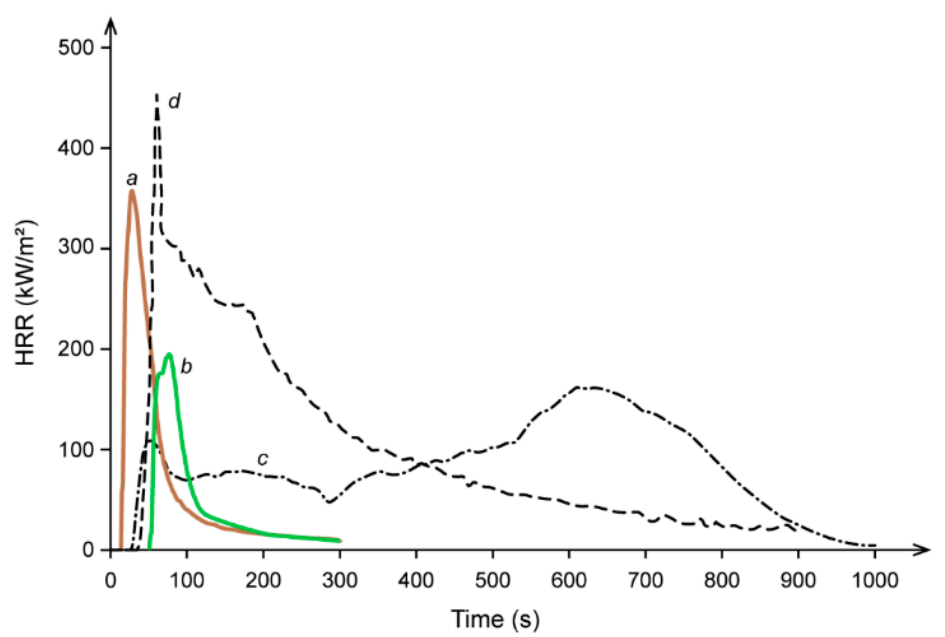

Figure 4. Comparison of HRR of vegetation parts of gorse shrub and typical roof coverings: (a) dead parts with dried leaves and twigs (redrawn from Madrigal et al. [58]); (b) green leaves (redrawn from Madrigal et al. [58]); (c) PMB membrane with fire retardants (redrawn from Bourbigot et al. [49]); (d) PMB membrane without fire retardants (redrawn from Thureson and Nilsson [48]).

When comparing these results to the roof membranes, it can be seen that both membranes release heat at much higher levels and for a much longer period, suggesting a greater potential contribution to the severity of a fire.

Some data can be found in the literature on plant flammability obtained in large and intermediate scale tests, which can be more realistic. For example, the pHRR of a small rockrose shrub (with up $3-20 \% \mathrm{MC}$ in its leaves) was $228 \mathrm{~kW}$ [59]. With a rapid decrease after the peak, the flameout appeared in less than a minute, leaving the sample to be only partly consumed. Overholt et al. [60] studied the 
fire behavior of tall grass (little bluestem) with a $7 \% \mathrm{MC}$, which can be associated with semi-intensive greening. The experiments on the whole plant showed a range of pHRRs from 35 to $75 \mathrm{~kW}$ for a single plant. In one minute, on average, the plants were completely burned. For a multiple plant setups with different stand densities, pHRR varied between 45 and $160 \mathrm{~kW}$. In all cases, pHRRs were reached in the first minute, after which they rapidly fell to values between 0 and $50 \mathrm{~kW}$. The research data on the fire behavior of coniferous trees, known as highly flammable fuels, are also available. A large-scale experimental testing of Christmas trees (Douglas Fir and Noble Pine) was conducted by Damant and Nurbakhsh [61]. It was shown that the pHRR of a whole dried Christmas tree (very dense Douglas Fir) of around 2-m tall can reach $1667 \mathrm{~kW}$, an extremely elevated value. For a cut and partly dried tree, pHRR reached $831 \mathrm{~kW}$. However, it is not expected that a cut Christmas tree would be installed on a green roof. Thus, these results cannot be used for a comparison with the present study. For a freshly cut tree, the measured pHRR was only $11 \mathrm{~kW}$, exhibiting a negligible amount of total heat released. As for other types of vegetation presented in Figure 4, the available tree fuel was rapidly consumed by fire, followed by a quick flameout. The experimental study of Jervis and Rein [13] on pine needles showed pHRRs of $252 \mathrm{~kW} / \mathrm{m}^{2}$ and $472 \mathrm{~kW} / \mathrm{m}^{2}$ for live and dead material, respectively. However, the flaming period lasted only $34 \mathrm{~s}$ for live and $18 \mathrm{~s}$ for dead material. Nevertheless, high HRR of plants, even with a short duration of flaming, can present a risk of fire propagation in the presence of combustible materials nearby.

It is difficult to match the vegetation components of green roofs against typical roof coverings because of the different spatial arrangement of these materials. However, they still allow us to partially understand the fire hazard that such roofs present on the building in case of fire. It is shown that neither growing media with high OM content nor plants present a higher risk than a roof membrane made of polymer-modified bitumen with or without fire retardants. This means that green roofs can be more advantageous in terms of fire safety in this case. However, compared to other more fire-resistant or non-combustible roof coverings, like PVC or ballasted roofs, such advantages would not be expected.

It has to be noted that vegetation performance in terms of heat release does not fully represent the potential fire hazard, because other characteristics like ignitability, rate of flame spread, sustainability and characteristics of flames produced are important to consider as well [62].

\section{Conclusions}

The present work characterized green roof flammability characteristics. From the conducted tests on growing media and the available literature data on vegetation and roof membranes, several conclusions can be made.

Green roofs do not add a substantial amount of fire load, even with intensive greening. It is estimated that such roofs present almost the same fuel load as roofs covered by a PMB membrane with no fire retardants, adding up to $95 \%$ of the available fuel. Extensive green roofs present a very small amount of fuel, which, in case of fire, will not contribute a lot.

In terms of fire performance, such roofs are comparable to conventional bitumen roofs. The results also show that dry substrates produce a smaller amount of heat during combustion than a bitumen membrane. Experiments on the growing media for intensive greening $(15 \% \mathrm{OM})$ show a great influence of moisture content. In the dry state (most hazardous case), the growing media is much more ignitable than in the moist (natural) state. However, flames do not last more than $10 \mathrm{~min}$. The limitation of the experimental study was the consideration of only one moisture condition. Testing substrates with a range of possible MC would help us to better assess the effect of moisture. The vegetation components of a green roof can produce heat at a very high rate, but for a shorter period than bitumen membranes. The peak HRR of dead vegetation material greatly exceeds the value produced by a membrane with fire retardants, and is comparable with the value of a standard bitumen membrane.

The fire risk of the vegetation on rooftops must be assessed, including different flammability parameters, which is a challenging task, due to the complexity of plants' structures and the dependence of their parameters on surrounding conditions. Future research on flammability properties and the 
fuel parameters of vegetation planted on green roofs can give a more realistic understanding of the fire risks of such roofs.

Author Contributions: Conceptualization, N.G., P.B., C.D.; methodology, N.G., P.B. and C.D.; validation, C.D., N.G.; investigation, N.G.; resources, N.G.; writing—original draft preparation, N.G.; writing — review and editing, N.G., C.D., P.B., S.M., J.C.; visualization, N.G.; supervision, P.B., C.D.; funding acquisition, P.B. All authors have read and agreed to the published version of the manuscript.

Funding: The authors are grateful to the Natural Sciences and Engineering Research Council (NSERC) of Canada for the financial support through its Industrial Research Chair (IRC) and Collaborative Research and Development (CRD) programs (IRCPJ 461745-18 and RDCPJ 524504-18) as well as the industrial partners of the NSERC industrial chair on eco-responsible wood construction (CIRCERB).

Acknowledgments: The authors also acknowledge the Green Roof Working Group of the Green Building Council of Canada, Quebec's section for technical data and mobility funding.

Conflicts of Interest: The authors declare no conflict of interest.

\section{References}

1. Stovin, V.; Vesuviano, G.; Kasmin, H. The hydrological performance of a green roof test bed under UK climatic conditions. J. Hydrol. 2012, 414, 148-161. [CrossRef]

2. Yio, M.H.N.; Stovin, V.; Werdin, J.; Vesuviano, G. Experimental analysis of green roof substrate detention characteristics. Water Sci. Technol. 2013, 68, 1477-1486. [CrossRef] [PubMed]

3. Jaffal, I.; Ouldboukhitine, S.-E.; Belarbi, R. A comprehensive study of the impact of green roofs on building energy performance. Renew. Energy 2012, 43, 157-164. [CrossRef]

4. Jungels, J.; Rakow, D.A.; Allred, S.B.; Skelly, S.M. Attitudes and aesthetic reactions toward green roofs in the Northeastern United States. Landsc. Urban Plan. 2013, 117, 13-21. [CrossRef]

5. Brenneisen, S. The Benefits of Biodiversity from Green Roofs: Key Design Consequences. In Proceedings of the 1st North American Green Roof Conference: Greening Rooftops for Sustainable Communities, Chicago, IL, USA, 29-30 May 2003.

6. Meacham, B.; Poole, B.; Echeverria, J.B.; Cheng, R. Fire Safety Challenges of Green Buildings. In Fire Hazard Assessment of Lithium Ion Battery Energy Storage Systems; Springer Science and Business Media LLC: Berlin, Germany, 2012; pp. 22-24.

7. RBQ. Critères techniques visant la construction de toits végétalisés Quebec; RBQ: Montréal, QC, Canada, 2015; pp. 15-16.

8. National Building Code of Canada 2015; National Research Council of Canada: Ottawa, ON, Canada, 2015.

9. Portland Fire Bureau. Incident report RP180057217; Office of the State Fire Marshal: City of Portland, OR, USA, 2018; pp. 1-2.

10. LFB (London Fire Brigade). Roof Garden Alight-Ealing. Available online: www.london-fire.gov.uk/incidents/ 2018/august/roof-garden-alight-ealing/ (accessed on 14 August 2018).

11. Lin, S.; Sun, P.; Huang, X. Can peat soil support a flaming wildfire? Int. J. Wildland Fire 2019, $28,601$. [CrossRef]

12. Scarff, F.R.; Westoby, M. Leaf litter flammability in some semi-arid Australian woodlands. Funct. Ecol. 2006, 20, 745-752. [CrossRef]

13. Jervis, F.; Rein, G. Experimental study on the burning behaviour of Pinus halepensis needles using small-scale fire calorimetry of live, aged and dead samples. Fire Mater. 2015, 40, 385-395. [CrossRef]

14. Weise, D.R.; White, R.H.; Beall, F.C.; Etlinger, M. Use of the cone calorimeter to detect seasonal differences in selected combustion characteristics of ornamental vegetation. Int. J. Wildland Fire 2005, 14, 321. [CrossRef]

15. Dimitrakopoulos, A.; Papaioannou, K.K. Flammability Assessment of Mediterranean Forest Fuels. Fire Technol. 2001, 37, 143-152. [CrossRef]

16. Ministry of Housing, Communities \& Local Government. Fire Performance of Green Roofs and Walls; Department for Communities and Local Government: London, UK, 2013.

17. Breuning, J. Fire and wind on extensive green roofs. In Proceedings of the Greening Rooftops for Sustainable Communities Conference, Baltimore, MD, USA, 30 April-2 May 2008.

18. Hadjisophocleous, G.V.; Mehaffey, J.R. Fire Scenarios. In SFPE Handbook of Fire Protection Engineering; Springer Science and Business Media LLC: Berlin, Germany, 2016; pp. 1262-1288. 
19. Fontana, M.; Kohler, J.; Fischer, K.; De Sanctis, G. Fire Load Density. In SFPE Handbook of Fire Protection Engineering; Springer Science and Business Media LLC: Berlin, Germany, 2016; pp. 1131-1142.

20. Burgan, R.E. Estimating Live Fuel Moisture for the 1978 National Fire Danger Rating System; Research Paper INT-RP-226; USDA Forest Service, Intermountain Forest and Range Experiment Station: Ogden, UT, USA, $1979 ;$ p. 16.

21. Bond, W.J.; Van Wilgen, B.W. Fire and Plants; Chapman \& Hall: London, UK, 2012; pp. 16-32.

22. Rein, G. Smoldering Combustion. In SFPE Handbook of Fire Protection Engineering; Springer Science and Business Media LLC: Berlin, Germany, 2016; pp. 581-603.

23. Rothermel, R.C. A mathematical model for predicting fire spread in wildland fuels; Res. Pap. INT-115; USDA Forest ServiceOgden, UT: US Department of Agriculture, Intermountain Forest and Range Experiment Station: Ogden, UT, USA, 1972; p. 40.

24. Bradshaw, L.S.; Deeming, J.E.; Burgan, R.E.; Cohen, J.D. The 1978 National Fire-Danger Rating System: Technical Documentation; General Technical Report INT-169; United States Department of Agriculture Forest Service: Ogden, UT, USA, 1983.

25. Scott, J.H.; Burgan, R.E. Standard Fire Behavior Fuel Models: A Comprehensive Set For Use with Rothermel's Surface Fire Spread Model; General Technical Report RMRS-GTR-153; United States Department of Agriculture Forest Service: Ogden, UT, USA, 2005.

26. Wotton, B.M.; Alexander, M.E.; Taylor, S.W. Updates and Revisions to the 1992 Canadian Forest Fire Behavior Prediction System; Information Report GLC-X-10; Great Lakes Forestry Centre Sault Ste: Marie, ON, Canada, 2009 ; p. 45.

27. Anderson, W.R.; Cruz, M.G.; Fernandes, P.M.; McCaw, L.; Vega, J.A.; Bradstock, R.A.; Fogarty, L.; Gould, J.; McCarthy, G.; Marsden-Smedley, J.B.; et al. A generic, empirical-based model for predicting rate of fire spread in shrublands. Int. J. Wildland Fire 2015, 24, 443-460. [CrossRef]

28. Dalgleish, S.A.; Van Etten, E.J.; Stock, W.D.; Knuckey, C. Fuel dynamics and vegetation recovery after fire in a semiarid Australian shrubland. Int. J. Wildland Fire 2015, 24, 613-623. [CrossRef]

29. Marsden-Smedley, J.B.; Catchpole, W.R. Fire modelling in Tasmanian buttongrass moorlands. I. Fuel characteristics. Int. J. Wildland Fire 1995, 5, 203-214. [CrossRef]

30. Cheney, N.; Gould, J.; Catchpole, W. The Influence of Fuel, Weather and Fire Shape Variables on Fire-Spread in Grasslands. Int. J. Wildland Fire 1993, 3, 31-44. [CrossRef]

31. Rossiter, N.A.; A Setterfield, S.; Douglas, M.M.; Hutley, L.B. Testing the grass-fire cycle: Alien grass invasion in the tropical savannas of northern Australia. Divers. Distrib. 2003, 9, 169-176. [CrossRef]

32. Albini, F.A. Estimating wildfire behavior and effects; General Technical Report INT-GTR-30; Intermountain Forest Experiment Station: Ogden, UT, USA, 1976; p. 92.

33. Jefferson, P.G.; McCaughey, W.P.; May, K.; Woosaree, J.; Macfarlane, L.; Wright, S.M. Performance of American Native Grass Cultivars in the Canadian Prairie Provinces. Nativ. Plants J. 2002, 3, 24-33. [CrossRef]

34. Kidnie, S.M. Fuel load and fire behaviour in the southern Ontario tallgrass prairie. Master's Thesis, University of Toronto, Toronto, ON, Canada, 2009.

35. Li, A.; Dhakal, S.; Glenn, N.F.; Spaete, L.P.; Shinneman, D.J.; Pilliod, D.S.; Arkle, R.S.; McIlroy, S.K. Lidar Aboveground Vegetation Biomass Estimates in Shrublands: Prediction, Uncertainties and Application to Coarser Scales. Remote. Sens. 2017, 9, 903. [CrossRef]

36. Marsden-Smedley, J.B.; Catchpole, W.R. Fire modelling in Tasmanian buttongrass moorlands. III. Dead fuel moisture. Int. J. Wildland Fire 2001, 10, 241-253. [CrossRef]

37. González-González, B.D.; Sixto, H.; Alberdi, I.; Esteban, L.; Guerrero, S.; Pasalodos, M.; Vázquez, A.; Cañellas, I. Estimation of shrub biomass availability along two geographical transects in the Iberian Peninsula for energy purposes. Biomass- Bioenergy 2017, 105, 211-218. [CrossRef]

38. Viana, H.; Vega-Nieva, D.J.; Torres, L.O.; Lousada, J.; Aranha, J. Fuel characterization and biomass combustion properties of selected native woody shrub species from Sep central Portugal and NW Spain. Fuel 2012, 102, 737-745. [CrossRef]

39. Scott Torrance Landscape Architecture Inc. City of Toronto Guidelines for Biodiverse Green Roofs; Toronto City Planning: Toronto, ON, Canada, 2013.

40. Sutton, R.K.; Harrington, J.A.; Skabelund, L.; MacDonagh, P.; Coffman, R.R.; Koch, G. Prairie-based green roofs: Literature, templates, and analogs. J. Green Build. 2012, 7, 143-172. [CrossRef] 
41. Greenbelt Native Plant Center, Green Roof Species List. Available online: www.nycgovparks.org/greening/ greenbelt-native-plant-center/garden-species-lists/garden-green-roof (accessed on 19 September 2019).

42. Heaton, E. A quantitative review comparing the yields of two candidate $\mathrm{C} 4$ perennial biomass crops in relation to nitrogen, temperature and water. Biomass- Bioenergy 2004, 27, 21-30. [CrossRef]

43. Zilverberg, C.; Teoh, K.; Boe, A.; Johnson, W.C.; Owens, V. Strategic use of native species on environmental gradients increases diversity and biomass relative to switchgrass monocultures. Agric. Ecosyst. Environ. 2016, 215, 110-121. [CrossRef]

44. DeBano, L.F.; Rice, R.M.; Eugene, C.C. Soil heating in chaparral fires: Effects on soil properties, plant nutrients, erosion, and runoff; Research Paper PSW-RP-145; Pacific Southwest Forest and Range Experiment Station, Forest Service, Department of Agriculture: Berkeley, CA, USA, 1979; p. 21.

45. Beadle, N.C.W. Soil Temperatures during Forest Fires and Their Effect on the Survival of Vegetation. J. Ecol. 1940, 28, 180. [CrossRef]

46. Busse, M.D.; Hubbert, K.R.; Fiddler, G.O.; Shestak, C.J.; Powers, R.F. Lethal soil temperatures during burning of masticated forest residues. Int. J. Wildland Fire 2005, 14, 267. [CrossRef]

47. Babrauskas, V. The Cone Calorimeter. In SFPE Handbook of Fire Protection Engineering; Springer Science and Business Media LLC: Berlin, Germany, 2016; pp. 952-980.

48. Thureson, P.; Nilsson, M. Degradation of Fire Properties of Approved Products as a Result of Ageing, SP Repot 1994:61; Swedish National Testing and Research Institute: Borås, Sweden, 1994; p. 44.

49. Bourbigot, S.; Cerin, O.; Duquesne, S.; Clavel, N. Flame retardancy of bitumen: A calorimetry study. J. Fire Sci. 2012, 31, 112-130. [CrossRef]

50. Babrauskas, V.; Peacock, R.D. Heat release rate: The single most important variable in fire hazard. Fire Saf. J. 1992, 18, 255-272. [CrossRef]

51. ISO 5660-1. Reaction-to-Fire Tests-Heat Release, Smoke Production and Mass Loss Rate, Part. 1: Heat Release Rate (Cone Calorimeter Method) and Smoke Production Rate (Dynamic Measurement); International Organization for Standardization: Geneva, Switzerland, 2015.

52. Babrauskas, V. Specimen heat fluxes for bench-scale heat release rate testing. Fire Mater. 1995, 19, $243-252$. [CrossRef]

53. Sampson, C. Logistics of Agricultural-Based Biomass Feedstock for Saskatchewan, Research Report E7810; PAMI: Humboldt, SK, Canada, 2012; pp. 100-101.

54. Parmar, K. Biomass- An Overview on Composition Characteristics and Properties. IRA-Int. J. Appl. Sci. (ISSN 2455-4499) 2017, 7, 42. [CrossRef]

55. Madrigal, J.; Guijarro, M.; Hernando, C.; Díez, C.; Marino, E. Effective Heat of Combustion for Flaming Combustion of Mediterranean Forest Fuels. Fire Technol. 2010, 47, 461-474. [CrossRef]

56. Hirsch, K.G. Canadian Forest Fire Behavior Prediction (FBP) System: User's Guide; Special Report 7; Canadian Forest Service: Ottawa, ON, Canada, 1996; p. 122.

57. Dibble, A.C.; White, R.H.; Lebow, P.K. Combustion characteristics of north-eastern USA vegetation tested in the cone calorimeter: Invasive versus non-invasive plants. Int. J. Wildland Fire 2007, 16, 426-443. [CrossRef]

58. Madrigal, J.; Marino, E.; Guijarro, M.; Hernando, C.; Diez, C. Evaluation of the flammability of gorse (Ulex europaeus L.) managed by prescribed burning. Ann. For. Sci. 2011, 69, 387-397. [CrossRef]

59. Tramoni, J.-B.; Santoni, P.-A.; Morandini, F. Experimental and numerical investigation of shrub combustion. J. Physics: Conf. Ser. 2018, 1107, 052002. [CrossRef]

60. Overholt, K.; Kurzawski, A.; Cabrera, J.; Koopersmith, M.; Ezekoye, O. Fire behavior and heat fluxes for lab-scale burning of little bluestem grass. Fire Saf. J. 2014, 67, 70-81. [CrossRef]

61. Damant, G.H.; Nurbakhsh, S. Christmas trees?what happens when they ignite? Fire Mater. 1994, $18,9-16$. [CrossRef]

62. White, R.H.; Zipperer, W.C. Testing and classification of individual plants for fire behaviour: Plant selection for the wildland-Urban interface. Int. J. Wildland Fire 2010, 19, 213-227. [CrossRef]

(C) 2020 by the authors. Licensee MDPI, Basel, Switzerland. This article is an open access article distributed under the terms and conditions of the Creative Commons Attribution (CC BY) license (http://creativecommons.org/licenses/by/4.0/). 